\title{
Which contractor selection methodology?
}

\author{
Abutorab Alirezaie and Seyyed Javad Razavi khosroshahi*
}

Department of Management and Accounting, South Tehran Branch, Islamic Azad University, Tehran, Iran

\section{H R O N I C L E}

Article history:

Received December 10, 2013

Received in revised format

25 June 2014

Accepted June 262014

Available online

July 32014

Keywords:

Contractor selection

Profitability

Kayson company

\section{A B S T R A C T}

\begin{abstract}
Contractor selection plays essential role on development of business industries and any selection strategy is normally involved with various factors. This paper presents an empirical investigation to determine important factors influencing contractor selection to increase profitability. The proposed model of this paper is implemented for an Iranian constructor firm named Kayson Company located in city of Tehran, Iran. The study has been accomplished among top managers who worked for this firm. Using structural equation modeling, the study determines that five factors including performance, believes, flexibility, quality, price and services influence on profitability when a contractor is to be chosen.
\end{abstract}

(C) 2014 Growing Science Ltd. All rights reserved.

\section{Introduction}

Industrial awareness of the requirement for judicious construction contractor selection has attracted tremendous increase. Many studies of this client procurement decision have more been expanded upon; specifically, by work accomplished in the USA and UK. Other countries are addressing the issue and procurement research abounds. Holt (1998) reported increased activity by presenting a review of contractor assessment and selection modelling methodologies including Bespoke approaches, Multi-attribute analysis, Multi-attribute utility theory. Fong and Choi (2000) examined an alternative contractor selection technique named the analytical hierarchy process (AHP) (Saaty, 1988, 1990), which would help construction clients to determine contractors with the best potential to deliver satisfactory results in a final contractor selection process, which is not primarily based on the lowest prices. Their AHP included three parts: hierarchic structure, prioritization procedure, and calculation of computations. They examined the model by a hypothetical scenario where three contractor candidates were assessed. They provided criteria for contractor selection in the model and the significance of each criterion has been reached at by executing a questionnaire survey in public firms in Hong Kong. Comparisons were built by ranking the aggregate scores of each candidate in terms of their performance against each of the criteria, and the candidate associated with the highest scores was the best contractor on this occasion.

* Corresponding author Tel : +989124548665

E-mail address: javadrazavi2006@yahoo.com (S. J. Razavi Khosroshahi)

(C) 2014 Growing Science Ltd. All rights reserved.

doi: $10.5267 /$ j.uscm.2014.7.003 
Jharkharia and Shankar (2007) presented a technique for the selection of a logistic service provider, which consisted of two parts: (i) preliminary screening of the available providers, and (ii) analytic network process (ANP)-based final selection (Saaty, 2004, 2005). The criteria, which were relevant in the selection of a provider, were identified and applied to they were build an ANP model. According to Cheng and Li (2004), contractor selection is one of the most important clients' activities and requires an appropriate technique to measure the effects of various factors influencing on the performance of the project. The multi-criteria decision-making (MCDM) such as AHP or ANP techniques is a common method for contractor selection.

Contractor selection is a complicated process to ensure the success of construction projects. Yawei et al. (2005) proposed a Multiple-layer Fuzzy Pattern Recognition (MFPR) method to solve contractor selection problem. They used the paired comparison method to decide relative membership degrees of qualitative criteria as well as weights of the criteria set by integrating judgments, experience and preferences of decision-makers. They applied their method for a case study for a channel construction project to show the feasibility of their method. Their findings clearly indicated that the methods could successfully harmonize various opinions and reach a group consensus.

\section{The proposed study}

This paper presents an empirical investigation to determine important factors influencing contractor selection to increase profitability. The proposed model of this paper is implemented for an Iranian constructor firm named Kayson Company located in city of Tehran, Iran. The study has been accomplished among top managers who work for this firm. The study first uses a Delphi technique to gather important factors influencing on profitability of firm when a contractor is to be selected. The proposed study of this paper repeats the process of Delphi technique three times and finally ends up having limited number of factors summarized in Table 1 as follows,

\section{Table 1}

The summary of factors influencing profitability during the procedure of contractor selection

\begin{tabular}{lcl}
\hline Factor & Cronbach alpha & Criteria \\
\hline \multirow{2}{*}{ Quality (Q) } & 0.95 & $\begin{array}{l}\text { Quality of online information } \\
\text { Quality of online payments } \\
\text { Quality of product }\end{array}$ \\
& & $\begin{array}{l}\text { Quality of workflow information } \\
\text { Quality of ordering process }\end{array}$ \\
\hline Cost (C) & 0.96 & $\begin{array}{l}\text { Cost of product } \\
\text { Transportation cost }\end{array}$ \\
\hline Delivery (Del) & 0.95 & Amount of delay in due date \\
& & On time delivery \\
Services (Serv) & & Responsiveness \\
& & $\begin{array}{l}\text { Customer support } \\
\text { Ability to access to information }\end{array}$ \\
\hline Flexibility (Flex) & 0.95 & Online delivery service supports \\
\hline & & Reaction to change on demand \\
Trust (Tru) & - & Website security \\
& & Reliability \\
\hline Past performance (Per) & 0.90 & Assurance \\
\hline Financial (Finance) & & Honesty, fidelity and loyalty \\
\hline Equipment (Equi) & 0.85 & Electronic transaction \\
\hline Location (Loca) & - & E-business capability \\
\hline & - & Financial \\
\hline
\end{tabular}


As we can observe from Table 1, all Cronbach alphas are within acceptable limits. The study uses structural equation modeling to examine the effects of all these factors on improving profitability. Table 2 demonstrates the summary of correlations among various components of the survey.

Table 2

The summary of correlation between different components

\begin{tabular}{|c|c|c|c|c|c|c|c|c|c|c|c|}
\hline & Flex & Tru & Per & Finance & Equi & Loca & Serv & Del & $\mathrm{C}$ & Q & Sale \\
\hline Flex & 1 & & & & & & & & & & \\
\hline Tru & 0.84 & 0.88 & & & & & & & & & \\
\hline Per & 0.85 & 0.82 & 0.93 & & & & & & & & \\
\hline Finance & 0.5 & 0.42 & 0.45 & 1 & & & & & & & \\
\hline Equi & 0.85 & 0.82 & 0.84 & 0.48 & 1 & & & & & & \\
\hline Loca & 0.24 & 0.22 & 0.19 & 0.56 & 0.22 & 1 & & & & & \\
\hline Serv & 0.93 & 0.72 & 0.74 & 0.47 & 0.86 & 0.21 & 0.93 & & & & \\
\hline Del & 0.93 & 0.83 & 0.83 & 0.47 & 0.84 & 0.21 & 0.74 & 0.94 & & & \\
\hline $\mathrm{C}$ & -0.97 & -0.86 & -0.87 & -0.48 & -0.88 & -0.23 & -0.87 & -0.85 & 0.98 & & \\
\hline Q & 0.86 & 0.86 & 0.87 & 0.45 & 0.87 & 0.2 & 0.78 & 0.75 & -0.88 & 0.92 & \\
\hline Sale & 0.87 & 0.67 & 0.81 & 0.46 & 0.86 & 0.18 & 0.88 & 0.85 & -0.98 & 0.89 & 0.93 \\
\hline
\end{tabular}

As we can observe from the results of Table 2, there are some positive and meaningful relationships among nearly all components of the survey when the level of significance is five percent. Next, we present details of the implementation of structural equation modeling.

\section{The results}

In this section, we present details of our findings on the effects of various factors on profitability when a supplier is chosen. Table 3 shows details of some basic statistics for the SEM implementation.

Table 3

Fit indexes of model

\begin{tabular}{cccccccccc}
\hline Index & P_value & $\chi^{2} /$ df & RMSEA & CFI & NFI & NNFI & GFI & IFI & RMR \\
\hline Acceptable Value & $<0.05$ & $<5$ & $<0.1$ & $>0.9$ & $>0.9$ & $>0.9$ & $>0.9$ & $>0.9$ & $<0.05$ \\
Value & 0.00 & 1.47 & 0.044 & 0.99 & 0.97 & 0.99 & 0.92 & 0.99 & 0.030 \\
\hline
\end{tabular}

As we can observe from the results of Table 3, all components are within acceptable levels, which verify the overall survey. Fig. 1 demonstrates the summary of the final model.

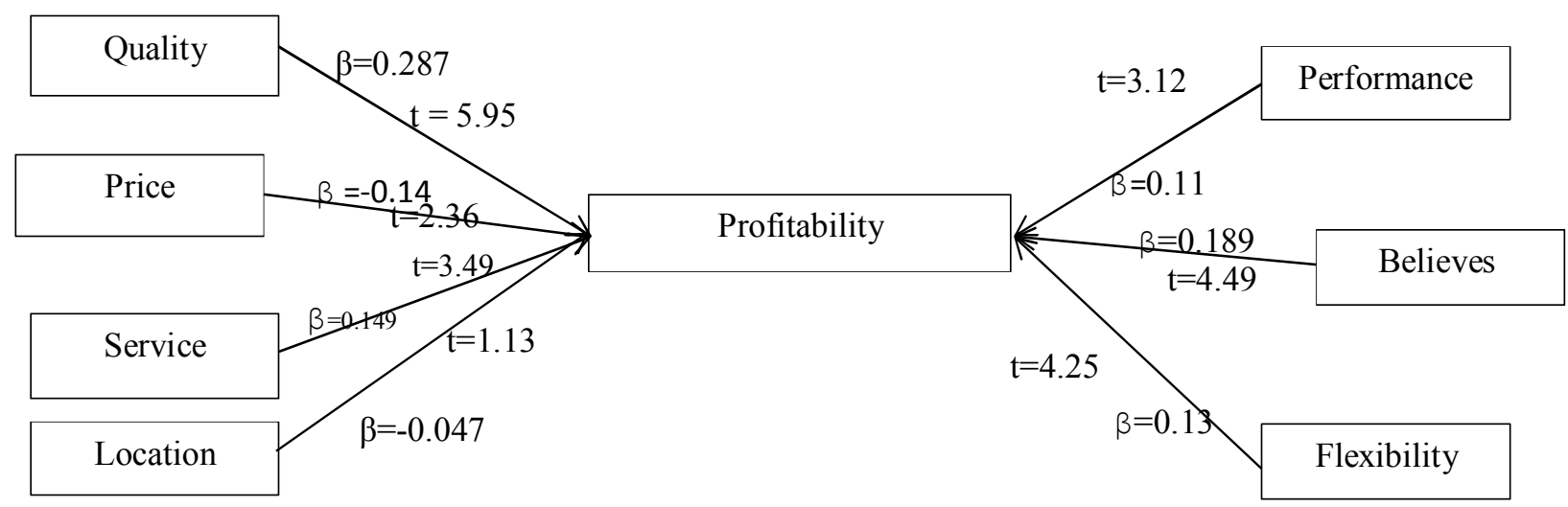

Fig. 1. The results of the implementation of structural equation modeling 


\section{Discussion and conclusion}

As we can observe from the results of Fig. 1, the effects of quality, price, service, performance, believes and flexibility on increasing the profitability have been approved. However, the effect of location has not been confirmed. In addition, while price maintains a negative impact on profitability, other components have had positive impacts on profitability. In other words, an increase on quality helps contractors provide better services, which reduces unexpected expenditures and increases profitability. In addition, quality seems to have the highest impact compared with other influential factors followed by contractors' believes and service. The results of our study are consistent with findings reported by Hilt (1998).

\section{Acknowledgement}

The authors would like to thank the anonymous referees for constructive comments on earlier version of this paper.

\section{References}

Cheng, E. W., \& Li, H. (2004). Contractor selection using the analytic network process. Construction Management and Economics, 22(10), 1021-1032.

Fong, P. S. W., \& Choi, S. K. Y. (2000). Final contractor selection using the analytical hierarchy process. Construction Management \& Economics, 18(5), 547-557.

Holt, G. D. (1998). Which contractor selection methodology?. International Journal of project management, 16(3), 153-164.

Jharkharia, S., \& Shankar, R. (2007). Selection of logistics service provider: An analytic network process (ANP) approach. Omega, 35(3), 274-289.

Saaty, T. L. (1988). What is the analytic hierarchy process? (pp. 109-121). Springer Berlin Heidelberg.

Saaty, T. L. (1990). How to make a decision: the analytic hierarchy process. European journal of operational research, 48(1), 9-26.

Saaty, T. L. (2004). Fundamentals of the analytic network process-multiple networks with benefits, costs, opportunities and risks. journal of systems science and systems engineering, 13(3), 348-379.

Saaty, T. L. (2005). Theory and applications of the analytic network process: decision making with benefits, opportunities, costs, and risks. RWS publications.

Yawei, L., Shouyu, C., \& Xiangtian, N. (2005). Fuzzy pattern recognition approach to construction contractor selection. Fuzzy Optimization and Decision Making, 4(2), 103-118. 